\title{
Anthropomorphism in Literature with Specific Reference to John Grogan's "Marley and Me"
}

\author{
M. Hannah Shirley and B. Monika Nair \\ Department of English and Foreign Languages, SRM Institute of Science and Technology \\ Kattankulathur - 603203 Chengalpattu District, Tamil Nadu, India
}

\section{ABSTRACT}

The concept of continuity between humans and other animals is found in Charles Darwin's thesis "The Descent of Man." Animals may serve as stand-ins for humans or human characteristics, as in Native American trickster tales or the Greek storyteller Aesop's fables. Various researchers have attempted to rebuild the concept of animality. Animality is an abstraction or a concept based upon actual animals' observations similar to human beings. Beyond basic emotions, animals also experience greed, forgiveness, forgetfulness, jealousy, suspicion, gratitude, curiosity, etc. We find a growing imperative need on this particular topic. Anthropomorphism, sometimes referred to as personification, is a well-established literary device from ancient times. It dates back to Aesop's Fables of the 6th century. The collections of fables from India, such as the Jataka Tales and Panchatantra, employ anthropomorphized animals to illustrate the principles of life. This paper aims to portray the concept of anthropomorphism found in canines with specific reference to the novel "Marley and Me" by John Grogan.

KEY WORDS: HUMAN CHARACTERISTICS; PERSONIFICATION; EMOTIONS; ANTHROPOMORPHISM; CANINES; THEORY OF MIND.

\section{INTRODUCTION}

Since the start of human history, people have lived in close contact with animals, usually as hunters and farmers, and have developed myths and legends about them. Different creatures like frogs, leopards and spiders play essential roles in mythology. The myths have given special meaning or extraordinary qualities to common animals like frogs, spiders, bears, rats. However, other creatures found in myths-many-headed monsters, dragons, and unicorns never existed within the world.

Animals as humans or human characteristics are seen in Aesop's fables and African American trickster tales. In few legends, animals perform various heroic deeds and is a source of connection between Heaven and Earth. Animals often have a dualistic quality in mythology. They can be either helpful to humans or harmful and

Biosc Biotech Res Comm P-ISSN: 0974-6455 E-ISSN: 2321-4007

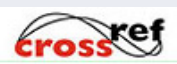

Identifiers and Pagination

Year: 2021 Vol: 14 No (8) Special Issue

Pages: 195-199

This is an open access article under Creative

Commons License Attribn 4.0 Intl (CC-BY). DOI: $h$ ttp://dx.doi.org/10.21786/bbrc/14.8.45 sometimes both. As sources and symbols, animals represent the real world's mystery and power that is by creation or destruction. Many myths have explored the relationships between humans and animals. Human beings may talk with animals, fight them and sometimes marry them. Animals perform services for humans, like guiding them through the underworld or completing tasks. A huge group of myths involving animals deals with changes between humans and animal states, and others focus about the close connection between people and animals.

The Fairy tale 'Enchanted Frog' were a princess kisses a frog, which transforms into a handsome prince and both of them live "happily ever after." Such transformations were people turn into animals or animals turn into people often is portrayed in stories around the world. Transformation myths talks about crossing the boundaries which keeps humans apart from the rest of the world. Dogs always appear in a positive light as the symbol of friendship and loyalty. In Greek and Roman mythology, the three-headed dog Cerberus is portrayed as a guardian. In many cultures dogs are seen either as symbol of death or protection. It is strongly believed by the ancient Egyptians and Aztecs of Mexico that dogs guided the dead on their afterlife journey.
Article Information

Received: $08^{\text {th }}$ June 2021 ccepted after revision: $20^{\text {th }}$ July 2021 
Fairy Tales And Fables: The first fairy tales and fables came into being more than a thousand years ago. Animals play a vital role in all the fairy tales at least one talking animal or mythical creature like a beast, an elf, or a unicorn appears. In the oral tradition of fairy tales, there are different versions of certain fairy tales. Though the animal characters used in them never change. It can be illustrated using the examples of the fairy tale "Little Red Riding Hood" and the fable "The Fox and the Crow," Fairy Tales are well-known short stories that are not based on actual events. In some fairy tales, magical element like witchcraft is also involved. Fairy tales stresses on the fact that they have a happy ending indicated by the phrase "happily ever after." In most cases, fairy tales do not imply a moral; they are merely written to entertain children and adults. Fables are shorter than fairy tales. Fables deals exclusively with animal characters. There is a possibility that the whole story of the fable could happen to humans in real life. The major difference between fairy tales and fables is that fables do not have a happy ending. The lesson that should be drawn from the fable is that life has both good and bad endings and that serves to be the basis for the moral.

Animal Tales: Animal tales on the other hand are short stories that are quite unknown and most of which remain anonymous. Like fables, animal tales also deals with animals as major characters. However, fables and animal tales do not imply a moral. Yet there is a mild difference the latter is distinguished by the lack of a clear moral message and usually attempts to explain certain animal traits. The major purpose of animal tales is to entertain.

The Funny Animal: The funny animal is a comics genre in which animals wear clothes, live in houses, drive vehicles, and have jobs, whereas other animal cartoon characters display anthropomorphic characteristics such as speaking or displaying facial expressions. Animal characters in the jatakas portray Buddha's teachings, which aim to bring happiness to humankind and all living beings around the world. To achieve this aim, Buddha had conveyed his compassionate message in many ways and various aspects through stories in which animal characters play a central role. Moreover, a large number of the characters in the Jataka stories are animals. The doctrines of karma and rebirth are also the sources for the construction of authentically Buddhist environmental ethics. The Jataka account of the Buddha's former births enlightens the readers about Buddhist teaching and how it urges respect for animals.

Animality: Animals have lived in the same way as humans. Animality has been defined by what it lacks. The search for the unique defining trait of humanity has involved underestimating other animals. Animality is an abstraction, or concept, loosely based upon actual animals' observations and sometimes relevant to human beings. Since the middle of the nineteenth century, when Charles Darwin asserted the idea of continuity between humans and other animals, researchers have attempted to rebuild the idea of Animality. It has been necessary to establish that animals experience emotions beyond basic ones. Darwin himself began this work in his magnum opus 'The Expression of the Emotions in Man and Animals. The animal as a teacher is evident in children's books, where they appear in a range of roles. In picture books, animals' images are often anthropomorphic and visual representations of the animal, reflecting and constructing cultural values. Many children's books are about companion animals (pets), but they seldom feature farm animals or animals' rights. Young children may learn about an animal's status through familiarity with religious customs and beliefs (Taylor Chloe, 2009). An animal can become a teacher about conservation, especially when a behavioral change is desired (Davey, 2006), although at the cost of its freedom.

Anthropomorphism In The Novel And Its Adaptation: Anthropomorphism as a concept deals with giving human characteristics to objects and animals. Anthropomorphizing is a natural human tendency designed to find order in a complex world. Pets are normal subjects: a dog's low, rapid tail wagging explained as guilt for eating a shoe; a cat rubbing against its owner interpreted as an expression of fondness. Research in the recently developed field of cognitive ethology, in essence, accumulates empirical data on just the kinds of mental states that anthropomorphisms claim (without the backing of science): the purposes, feelings, motivations, and cognition of animals (Horowitz A. 2007).

In the book and its adaptation 'Marley and Me' by John Grogan, a Labrador retriever is used to convey the concept of Anthropomorphism. Some of the other most notable examples are the Walt Disney characters, the Magic Carpet from Disney's Aladdin franchise, Mickey Mouse, Donald Duck, Goofy, Oswald the Lucky Rabbit; the Looney Tunes characters and others from the 1920s to the present day. In the motion picture Fantastic Mr. Fox (2009), most of the characters are anthropomorphic animals very similar to the Furry Fandom style. They are given human characteristics such as body shape, hands, and clothing, among other things (Felicia M Jones).

Labrador retrievers are generally considered eventempered, calm, and reliable, and then there is Marley, the subject of this delightful tribute to one Lab, who does not fit the mold. Grogan uses Marley's story as a vehicle for sharing his insight into experiences many people in their twenties, thirties, and early forties share. The book covers his newlywed years, the ups and downs of trying to start a family, homeownership and neighborhood issues, and career evolution. Grogan contends that there is a lot we can learn from our pets. The story is so honest and well-written that it will resonate with pet lovers and pet-deprived people alike. His novel Marley and Me spent seventy-six weeks on the bestseller list and later made into a movie.

Marley \& Me is a loveable story about a family and their naughty dog named Marley. Grogan and Jenny Grogan were beginning their life together. They had everything a young couple desired, a cute little house, good jobs, and 
the love for each other. They just wanted one more thing, a puppy. From that day onwards they had a different life altogether. They brought home Marley, a cute yellow puppy. He grew up quickly into a full-grown 97-pound crazy furball. He made a huge mess flung drool on guests, and ate nearly everything he could get. Obedience school did not do any good; he was expelled after the first few classes. The medication was no relief to him either, and he was scared when a thunderstorm rolled by. However, he was probably the most loyal dog that the family had ever known in the end.

Grogan, the author and the hero of the story was always fond of dogs ever since his father gifted him one when he was a child. He and his wife, Jenny, both work for newspapers and live in Florida. One day he sees his wife Jenny looking at an advertisement for a Labrador puppy. She believes that looking after a dog would be good preparation for looking after a baby. They drive to the kennel and decide to choose a puppy that has taken an interest in them. They inquire about the puppy's father, but the dog's owner seems reluctant to talk about him. They are told to return and collect the dog in three weeks (Cremin ,2009).

While they are driving away, they see a wild-looking dog in the woods, and Grogan assumes that it must be the puppy's father. They decide to name the puppy Marley, after the late singer Bob Marley. While Jenny goes for a vacation with her sister, Grogan brings Marley home. Marley is a notorious dog who loves to have people around and gets excited chewing things. Jenny and Grogan take him for walks on the beach, where they discover he is uncontrollable. The couple discovers that Marley has a caring and loving heart, when he grieves along with them when they suffered the miscarriage. The couple not being able to control Marley decides to take him to a dog obedience class. Marley misbehaves, and the teacher rebukes the owners for not being strict with him and for not letting him know who the boss is. In the second class, the teacher tries to restrain Marley but fails. She uses the excuse that Marley is too young and tells Grogan not to bring him back to the class. The couple talks to their friend, Dr. Jay, who recommends that he neuter Marley to calm him down.

A week later, while driving to the doctor's, Marley tries to jump out of the car and causes a traffic congestion. He is later neutered and appears very relaxed after the operation. The couple decides a vacation to Ireland, leaving Marley at home in the care of Kathy, a colleague of Grogan. When they return, they are met by an exhausted Kathy, who seems to hurry to get away from the dog. Jenny later delivers a child and they name him Patrick. Marley loves this newcomer to the family and stays by his side. They soon become a bigger family, as Jenny conceives for the second time. One October night, Grogan hears a girl's cry in the street. He goes outside along with Marley and finds his neighbor's daughter covered in blood. A man had attacked her, and the police arrive immediately. Luckily, she survives. Jenny's second pregnancy proves to be problematic, and she has to stay in bed for a long time. During this time, Marley stays with her as a good companion. The baby is born, and they name him Connor. At first, everything appears fine. However, his wife develops post-partum depression and starts to behave violently.

Grogan comes home after work and finds Jenny beating Marley because he had broken several things in the house. Then, she says she does not want the dog anymore. Grogan decides to try the obedience classes again with the help of a new teacher, Marley begins to develop a good behaviour. Jenny returns to normal, and the family seems to be happy again. When a friend of Jenny's, who works for a film company, asks if they could use Marley in a film they were making, the couple immediately agrees. A couple of years later, the family watches the film and their famous dog Marley's small part in it. The family wants to move to a better neighborhood and buy a house in the up-market town of Boca Raton. They decide to go for a drink at a roadside restaurant. They tie Marley to a heavy table, but he drags the table and chases a stray dog across the street. Marley crashed his way through the sea of other tables. Jenny and Grogan retrieve the table to the other customers.

On Grogan's fortieth birthday, everyone is feeling tired, and they do not celebrate it. Grogan being sad about it wants to have a drink with a friend in a bar. At the bar Grogan receives a call from Jenny who tricks him to believe that the baby was crying frantically and that he should come home immediately. On his arrival he was astonished to see a surprise party arranged for him. One day, Marley misbehaves at the beach by drinking a lot of seawater and by dirtying all over. Grogan is upset and decides not to take Marley to the beach again. Grogan and his family relocate to a house in the countryside near Pennsylvania. The family loves their new house, and Marley enjoys the countryside and snow. Marley is now nine years old, and Grogan notices that he is moving much more slowly and also, he suspects that Marley is going deaf.

Marley turns twelve, and that scares the couple. They have a fright one night when Marley disappears while Grogan takes him for a walk on a cold and wet night. They find him eventually and bring him back. Marley's health deteriorates quickly: his fur falls out, he starts losing his sight, and his hips starts causing pain. Gastric dilatation-volvulus almost kills him, but he recovers. When Grogan gets a new and more demanding job, and Jenny goes to visit her sister, they put Marley in a dog home. A short time later, they receive a call from the dog's home stating that Marley is very sick and might need to think about putting him down. Grogan calls his wife, and they agree to do this. However, Marley makes a partial recovery, and Grogan takes him back home. He cannot move and falls of the stairs. Grogan realizes the bitter truth that Marley will die soon. When Marley has a second attack, it was very evident that he would not make it. Marley is then euthanized with Grogan beside him. He dies quietly with its owner grieving by his side. 
The family pays their deference to their beloved pet as they bury him beneath a tree in their yard. Grogan remembers the times with Marley. Though Marley was uncouth and Imbecile they loved him for what he was. Marley has many faults, but the family tolerates him for his unconditional love. Looking at the positive side of the animal or a human being is the crux of the entire story (Cremin ,2009).

Quotations In The Novel: The concept of anthropomorphism is vividly seen in the novel through the various quotes provided below. Grogan went to help a girl who a stranger threatened with a knife. Seconds later, Grogan was surprised to see Marley's fighter attitude within. It was not till later that he noticed Marley standing there in protection mode which made him feel safe. Previously, Marley was just a dumb, silly pal; now, he has become a loyal guard dog. "When I searched, there he stood, ten feet from us, facing the road, during a determined, bulllike crouch I had never seen before. It was a fighter's stance. His muscles bulged at the neck; his jaw was clenched; the fur between his shoulder blades bristled" (Grogan 150).

He was intensely focused on the road and appeared poised to lunge. Grogan realized in that instant that Jenny had been right. If the armed assailant returned, he would need to get past his dog first. At that moment, he knew without a doubt- that Marley would fight him to death. Even after moving to Pennsylvania, Marley could adjust to the weather and be his old self. In this passage, Grogan uses much imagery to explain Marley's crazy actions, which adds to the story. His word choice and overall writing set a very joyful, happy mood to the scene. "Thw Abominable Snowdog. Marley didn't know what to form of this foreign substance. He jammed his nose deep into it and set free a violent sneeze. He snapped at it and rubbed his face into it. Then, as if an invisible hand reached down from the heavens and jabbed with an enormous shot of adrenaline, he took off at full throttle, racing round the yard in a series of giant, loping leaps interrupted every several feet by a random somersault or nosedive" (Grogan 222).

Marley knows how to make life joyful and happy and adapt to the new climatic setup. Grogan and Jenny's usually crazy hyper dog whom they knew their whole life started showcasing gentleness. He realizes that a baby is more delicate and does not act as frantic around the newborn. The couple now develops respect towards Marley. "One night early, as I used to be turning off the lights to travel to bed, I couldn't find Marley anywhere. Finally, I assumed to seem within the nursery, and there he was, stretched on the ground beside Patrick's crib, the 2 of them snoring away in stereophonic fraternal bliss. Marley, our wild crashing bronco, was different around Patrick" (Grogan 109). As Marley got older, he developed arthritis in his joints and had much trouble running his everyday life. The stairs were one of the hardest things for him, and it showed how loyal he was to Grogan and Jenny that he faced the pain every night multiple times to stay with them. Because it was stupid to do, Grogan and Jenny treated him with sympathy and tried to eliminate some pain by sneaking, but it never seemed to work. He lived with the suffering and never complained or stopped for anything.

"No matter how much trouble he had getting up the stairs, if I returned downstairs, say to grab a book or turn off the lights, he would be right on my heels, clomping heavily down behind me. Then seconds later, he would have to repeat the torturous climb. Jenny and I both took to sneaking around behind his back one he was upstairs for the night so he would not be tempted to follow us back down" (Grogan 241). After Marley died, there seemed to be ample space in the Grogans' lives. He came inside one morning from finding the perfect place to bury Marley and saw his kids crying. "Yes, it was only a dog, and dogs come and go in the course of human life, sometimes simply because they became an inconvenience. It was a dog, and yet every time I tried to talk about Marley to them, tears welled in my eyes" (Grogan 274). He tried to explain to them that everything was ok and they would be fine, but Grogan himself was having a hard time dealing with the fact that Marley was not coming back. Grogan says he is the kind of person who never cries at funerals, but a dog made him soften up for some reason.

Grogan decided to write a column about his story with the world's best and worst dog ever. He wrote it in tears, thinking of all the times he yelled at Marley for the bad things he did, and the fun times they had together. Marley, and any dog, is a lot more to a person's life than they ever expected. Grogan states that Marley taught him lessons about life that would be absent and unimportant to him without his companion's help. Grogan wanted to convey that an animal had touched their souls and taught them some of the most important lessons of life. "Marley taught me about living each day with unbridled exuberance and joy, about seizing the moment and following your heart. He taught me to appreciate the simple things-a walk in the woods, a fresh snowfall, a nap in a shaft of winter sunlight. Furthermore, as he grew old and achy, he taught me about optimism in the face of adversity. Mostly, he taught me about friendship and selflessness and, above all else, unwavering loyalty" (Grogan 279).

The strong bonding between the author and the dog raises the animal's standard and makes it appear humane. "A dog has no use for fancy cars or big homes or designer clothes. The status symbol means nothing to him. A waterlogged stick will do just fine. A dog judges others not by their color or creed, or class but by who they are inside. A dog does not care if you are rich or poor, educated or illiterate, clever or dull. Give him your heart, and he will give you his. It was quite simple, yet we humans, so much wiser and more sophisticated, have always had trouble figuring out what counts and what does not. As I wrote that farewell column to Marley, I realized it was all right there in front of us, if only we opened our eyes. Sometimes it took a dog with bad breath, worse manners, and pure intentions to help us 
see." After writing the novel, John Grogan got hundreds of e-mails and letters back from readers all over the city sharing their stories and giving their sympathy. His life changed forever because of the silly little dog that he initially thought ruined his life. Even with immature minds and destructive behaviors, dogs will always be a man's best friend. "If he were human, I would have called him certifiably psychotic. He was delusional, paranoid...." (Grogan 171).

\section{CONCLUSION}

Anthropomorphism is turning a real-life incident or an imaginary situation into a story. The intellectual and emotional roles that animals play allow children and their mentoring adults to become more reflective and critical concerning life problems and life choices (Graves, 1989). Education is not just mere factual learning, but it serves to be the place to develop their ability to imagine, create and act. Paving the way for learners to be independent, critical, and flexible will add more value to literature.

Children's literature deals with animals that have human attributes. Animals that talk create a sense of fantasy among young learners. As Derby rightly states, "Inanimate objects can do what people are not able to, or cannot." (Derby, 1970). Animals which are caricatures of certain types of people are funny to both adults and children. The humor is often based on the animal's picture and what it says, not by its verbal description. Anthropomorphism's humor may even yield to the senses of the youngest reader through picture books. Marley and Me by John Grogan explicitly deals with "the human companion-animal bond (HAB)", a bond that outdoes Marley's mischief. Elizabeth Anderson, in her book: Our Powerful Bond between People and Pets: Our Boundless Connection to Companion Animals" talks about the biological basis for HAB called "biophilia." According to her humans are "hard-wired for kinship with animals" Indeed, pet owners are even more attached to their pet than other people, as the former never criticizes, betrays, or rejects.

Given the abundance of HAB examples, it is no surprise that the movie (Marley and Me) was a blockbuster. The filmmakers were able to portray just how destructive a puppy can be. The dog's bonding and humane characterization are evident through various scenes in the film, such as Marley evicted from obedience school and his compassion and care towards Jenny and her children. Finally, watching Grogan biding adieu to Marley and the entire family mourning over his death reinstates the human role of animal in human's life. In conclusion, The book and its adaptation vividly portrayed Anthropomorphism through various scenes in the book and its adaptation. The film has played a significant role in portraying Marley's various humane characteristics through its visual composition. Anthropomorphism about canines can further be studied with the movie adaptation "Hachiko: A Dog's Tale" which deals with a real-life incident that took place in Japan.

\section{REFERENCES}

“Animals in Mythology." Myths Encyclopedia, www. mythencyclopedia.com/Am-Ar/Animals-in-Mythology. html.

Cremin, Teresa, et al.( 2009) "Teachers as Readers: Building Communities of Readers.” Literacy, vol. 43, no. 1, pp. 11-19. Crossref, doi:10.1111/j.17414369.2009.00515.x.

Davey, Gareth. (2006 ) "Visitor Behavior in Zoos: A Review.” Anthrozoös, vol. 19, no. 2, pp. 143-157., doi:10.2752/089279306785593838.

Graves, Donald. (1989) “ERIC - ED359552 Experiment with Fiction. The Reading/Writing Teacher's Companion Series.” ERIC, 30 Nov. 1988, eric. ed.gov/?id=ED359552.

Harper Collins.( 2005) "Marley \& Me.” HarperCollins, www.harpercollins.com/products/marley-me-johngrogan?variant=32132778328098.

Horowitz, Alexandra \& Bekoff, Marc. (2007). Anthropomorphism: Behavioral Prompts to Our Humanizing of Animals. Anthrozoos A Multidisciplinary Journal of The Interactions of People \& Animals. 20. 10.2752/089279307780216650.

James, Derby.( 1970) "Periodicals Received." English Studies, vol. 51, no. 2, pp. 190-92. Crossref, doi:10.1080/00138387008597372.

Lara Teupe. "The Function of Animals in Fairy Tales and Fables.” GRIN, www.grin.com/document/266944 Taylor, Chloë. (2012) "Kelly Oliver Animal Lessons: How They Teach Us to Be Human. New York, Columbia University Press, 2009." Hypatia, vol. 27, no. 3, pp. 672-75. Crossref, doi:10.1111/j.1527-2001.2012.01287. $\mathrm{X}$. 